\title{
Pulmonary Stretch Receptor Activity during Partial Liquid Ventilation in Cats with Healthy Lungs
}

\author{
Esther Rieger-Fackeldey ${ }^{a, b}$ Richard Sindelar ${ }^{a}$ Anders Jonzon $^{a}$ \\ Andreas Schulze ${ }^{b}$ Gunnar Sedin ${ }^{a}$ \\ aDepartment of Women's and Children's Health and Department of Physiology, Uppsala University, \\ Uppsala, Sweden; bDivision of Neonatology, Department of Obstetrics and Gynecology, Klinikum Grosshadern, \\ University of Munich, Munich, Germany
}

\section{Key Words}

Control of breathing $\cdot$ Slowly adapting pulmonary stretch receptor $\cdot$ Pressure controlled ventilation · Partial liquid ventilation

\begin{abstract}
Aim: To study whether pulmonary stretch receptor (PSR) activity in mechanically ventilated young cats with healthy lungs during partial liquid ventilation (PLV) is different from that during gas ventilation (GV). Methods: In 10 young cats $(4.4 \pm 0.4$ months, $2.3 \pm 0.3 \mathrm{~kg}$; mean \pm $\mathrm{SD})$, PSR instantaneous impulse frequency ( $P S R f_{\mathrm{imp}}$ ) was recorded from single fibres in the vagal nerve during GV and PLV with perfluorocarbon $(30 \mathrm{ml} / \mathrm{kg})$ at increasing positive inspiratory pressures (PIP; 1.2, 1.8, 2.2 and $2.7 \mathrm{kPa}$ ), and at a positive end-expiratory pressure of $0.5 \mathrm{kPa}$. Results: All PSRs studied during GV maintained their phasic character with increased impulse frequency during inspiration during PLV. Peak $P S R f_{\text {imp }}$ was lower at PIP $1.2 \mathrm{kPa}(p<0.05)$ and at PIP $2.7 \mathrm{kPa}(p=0.10)$ during PLV than during GV, giving a lower number of PSR impulses at these two settings during PLV $(p<0.05)$. Conclusion: The phasic character of PSR activity is similar during GV and PLV. PSR activity is not higher during PLV than during GV in cats with healthy lungs, indicating no extensive stretching of the lung during PLV.
\end{abstract}

Copyright () 2004 S. Karger AG, Basel

\begin{tabular}{ll}
\hline KARGER & ( ) 2004 S. Karger AG, Basel \\
0006-3126/04/0862-0073\$21.00/0 \\
$\begin{array}{l}\text { Fax +4161306 12 34 } \\
\begin{array}{l}\text { E-Mail karger@karger.ch } \\
\text { www.karger.com }\end{array}\end{array}$ & $\begin{array}{l}\text { Accessible online at: } \\
\text { www.karger.com/bon }\end{array}$
\end{tabular}

\section{Introduction}

Partial liquid ventilation (PLV) with perfluorocarbon (PFC) is a method of ventilatory support introduced by Fuhrman et al. [1] in 1991. The beneficial effects of PLV on gas exchange and lung mechanics have been explored in studies in animal models of respiratory distress [2, 3] and confirmed in humans [4]. It has also been proposed that PLV might offer some advantages in the treatment of newborn infants with lung disorders [5]. Also, in animals with healthy lungs, investigations of PLV have been performed regarding liquid distribution, lung mechanics, evaporative loss, and gas exchange [6-10]. Less attention has been paid to the effects of this form of ventilation on stretch receptor activity which is influenced by the distension of the lungs and might be of great importance during the course of and weaning from PLV [11].

During the cyclic events of breathing, airway and respiratory reflexes serve to protect lung tissue and promote lung capacity for gas exchange [12]. The peripheral lung receptors respond to dynamic changes with impulses [13] that are transmitted by the vagal nerve to the central nervous system. The slowly adapting pulmonary stretch receptors (PSRs) are located within the airway smooth muscle layer [14]. They appear to be far more numerous than rapidly adapting stretch receptors and are easily identifiable [15]. PSRs continuously sense the tension

Esther Rieger-Fackeldey, MD

Department of Women's and Children's Health

Children's University Hospital, Uppsala University

SE-75185 Uppsala (Sweden)

Tel. +4618 6115885, Fax +46 186115856 , E-Mail esther.fackeldey@kbh.uu.se 
within the myoelastic components of the airways [16] and respond to stretching of lung tissue mediated by changes in lung volume, transpulmonary pressure or airflow [17]. PSRs are involved in the control of breathing, with an increasing discharge during inspiration, and play an important role in the Hering-Breuer reflex [18], which is thought to be stronger in newborns than in adults $[19,20]$. PSRs are important modulators in the establishment of normal rhythmic control of breathing in the newborn infant [21].

The activity of PSRs has been studied extensively during gas ventilation (GV) $[15,22,23]$, but no data are available about their activity during PLV. The aim of this study was to analyze PSR activity, as an indicator of tissue stretching in animals with healthy lungs during PLV and GV, using pressure-controlled ventilation. Since the surface tension is lowered during PLV, potential overdistension of the alveoli might occur during this form of ventilation as a result of the high density of PFC. Activity of receptors located close to the airway lumen further down the bronchial tree might therefore reflect the surface tension of the air-liquid interface during $\mathrm{GV}$ and the liquidliquid interface during PLV. We hypothesized that PSR activity will be higher during PLV than during GV as a result of higher tissue stretching. We recorded PSR activity during PLV and during GV in young cats with healthy lungs and with intact respiratory reflexes in order to evaluate the PSR activity in relation to the pressures applied during these two types of ventilation.

\section{Methods}

\section{Animal Preparation}

Ten young cats (mean \pm SD; age $4.4 \pm 0.4$ months, weight $2.3 \pm$ $0.3 \mathrm{~kg}$ ) were anaesthetized with chloroform and placed in a supine position. An endotracheal tube ( $4.0 \mathrm{~mm}$ inner diameter) was inserted orally into the trachea and fixed tightly. The endotracheal tube was then connected to an infant ventilator (Stephanie ${ }^{\circledR}$, F. Stephan Biomedical Inc., Gackenbach, Germany) and the animal was placed on pressure-controlled mechanical ventilation during the surgical procedures, with the following settings: peak inspiratory pressure (PIP) $1.2 \mathrm{kPa}$, positive end-expiratory pressure (PEEP) $0.5 \mathrm{kPa}$, inspiratory time $1 \mathrm{~s}$, respiratory rate $30 / \mathrm{min}$, fraction of inspired oxygen $\left(\mathrm{FiO}_{2}\right) 0.21$.

The right femoral vein and artery were dissected and catheters were inserted into these vessels until their tips were placed in the thorax close to the heart. Anaesthesia was continued with $0.72 \% \alpha-$ chloralose (Sigma-Aldrich Chemie $\mathrm{GmbH}$, Steinheim, Germany) $(50 \mathrm{mg} / \mathrm{kg})$ and maintained via the venous line at regular intervals. A continuous infusion of $10 \%$ glucose $(2 / 3)$ and $5 \% 0.6 \mathrm{M}$ sodium bicarbonate $(1 / 3)$ was given at a rate of $6.4 \mathrm{ml} / \mathrm{kg} / \mathrm{h}(7.15 \mathrm{mg} / \mathrm{kg} / \mathrm{min}$ of glucose) throughout the experiment, using the venous catheter. The arterial line was used for continuous monitoring of blood pres- sure and intermittent determination of blood gases (Acid-Base Laboratory ABL $505^{\circledR}$, Radiometer Corp., Copenhagen, Denmark). Core body temperature of the cats as measured by deep rectal temperature was maintained at $38^{\circ} \mathrm{C}$ by a heating blanket and an overhead warmer.

A pretracheal midline incision was performed for preparation of the trachea, the oesophagus and both vagal nerves. A tight ligature was tied around the trachea to prevent air leakage around the endotracheal tube. An 8-Fr catheter with an oesophageal balloon $(40 \times$ $7.5 \mathrm{~mm}$; flat frequency response up to $5 \mathrm{~Hz}$ ) was inserted into the distal part of the oesophagus and a ligature was softly tied around the oesophagus to avoid entry of air into the stomach. Both vagal nerves were exposed and the connective sheath was removed. The right vagal nerve was placed on a platform, a slip of it was cut and this was further dissected into filaments under a microscope, leaving the major part of the nerve intact. The filaments were split into fine nerve strands, which were placed on a platinum electrode until single unit activity from a slowly adapting stretch receptor could be recorded. For reasons of isolation and to prevent drying out of the vagal nerves, the electrodes and the dissected area were submerged in mineral oil.

\section{Measurements and Data Collection}

Airflow was measured by a sensor placed between the endotracheal tube connector and the $\mathrm{Y}$ connector of the tubing circuit of the infant ventilator. This sensor is a pneumotachometer with the dynamic properties of an original Fleisch 00 pneumotachograph, but with less dead space $(0.6 \mathrm{ml})$ and resistance $(1.1 \mathrm{kPa} / 1 / \mathrm{s}$ at $5 \mathrm{l} / \mathrm{min})$ [24]. Airflow was calibrated with a precision flowmeter (Timeter RT $200^{\circledR}$, Timeter Instrument Corp., Lancaster, Pa., USA). Airway pressure $\left(\mathrm{P}_{\mathrm{aw}}\right)$ was measured at the adapter of the endotracheal tube. Oesophageal pressure $\left(\mathrm{P}_{\mathrm{es}}\right)$ was recorded from the oesophageal balloon catheter by a pressure transducer (Druck Ltd Transducer, Groby, Leics., UK) and, like $\mathrm{P}_{\mathrm{aw}}$ was calibrated with a water manometer. Arterial blood pressure was measured and heart rate recorded using the same type of transducer (Druck Ltd Transducer) connected to the arterial catheter with the tip of the catheter at the same level as the transducer. Continuous recordings of arterial blood pressure and heart rate were made with a polygraph recorder (Recorder $330 \mathrm{P}^{\circledR}$, Hellige AG, Freiburg, Germany).

Nerve signals from PSRs were amplified, filtered and rectified with a Neurolog System ${ }^{\circledR}$ (Digitimer Research Instrumentation Inc., Welwyn Garden City, Herts., UK; preampflifier NL 103, AC amplifier NL 105, filters NL 115). With the use of an analogue window discriminator (Digitimer D 130, Digitimer Research Instrumentation Inc.), only signals from a certain single fibre were recorded without background noise [25]. The signals were displayed on an oscilloscope (Tektronix Inc., Portland, Oreg., USA).

Signals of airflow and $\mathrm{P}_{\mathrm{aw}}$ were obtained directly from the analogue outlets of the ventilator. Together with signals of $\mathrm{P}_{\mathrm{es}}$ and the nerve activity, they were transferred to an analogue-digital converter and recorded on disk at a sampling rate of $10 \mathrm{kHz}$ per channel by a data acquisition system (Windaq Pro ${ }^{\circledR}$, Dataq Instruments Inc., Akron, Ohio, USA)

\section{Protocol}

Before the recordings were started the cats were kept normoventilated using controlled mechanical ventilation, as verified by arterial blood gases in the normal range i.e. $\mathrm{PaCO}_{2}$ of $4.4-5.6 \mathrm{kPa}$ and $\mathrm{pH}$ of 7.38-7.42. The cats were then submitted to periods of at least $4 \mathrm{~min}$ 
of pressure-controlled mechanical ventilation with a square wave inspiratory pressure waveform. PIPs of $1.2,1.8,2.2$ and $2.7 \mathrm{kPa}$, with a PEEP of $0.5 \mathrm{kPa}$, were applied, always in the same order. Respiratory rate given by the ventilator was set at $20 / \mathrm{min}$ (normal rate in cats: $10-20 / \mathrm{min}$ ), inspiratory time was set at $1 \mathrm{~s}$, and $\mathrm{FiO}_{2}$ was kept at 0.21 . Data from 15 consecutive breaths were recorded at the end of each of these four ventilatory periods, followed by determination of arterial blood gases.

Thereafter a bolus of $30 \mathrm{ml} / \mathrm{kg}$ prewarmed $\left(38^{\circ} \mathrm{C}\right)$ perfluorocarbon (Perfluorodecaline ${ }^{\circledR}$, F2 Chemicals Ltd, Preston, Lancs., UK) was instilled within $10 \mathrm{~min}$ into the endotracheal tube via an adapter with a side port, while PIP was increased to $2.2 \mathrm{kPa}$ and $\mathrm{FiO}_{2}$ to 1.0 . Sufficient filling was ascertained by disconnecting the animal from the ventilator at the end of the filling procedure and observing that a meniscus could be seen at the endotracheal tube at end-expiration. If no meniscus could be observed prior to recording, additional PFC was added. After a stabilization period of $10 \mathrm{~min}$, the cats were submitted to four ventilatory periods with the same ventilatory patterns, PIP and PEEP as used previously during GV, but with $\mathrm{FiO}_{2}$ of 1.0. The order of the different PIP levels was reversed in every other cat when PLV was used. Recordings and determination of blood gases were performed as previously described.

The experiments were performed at the Biomedical Centre of Uppsala University and were approved by the Uppsala University Animal Research Ethics Board (No. C 224/0).

\section{Data Analysis and Statistics}

Windaq Playback ${ }^{\circledR}$ Software (Dataq Instruments, Inc.) was used to review the recorded signals. Analyses were performed by Windaq Playback $^{\circledR}$ and Excel $^{\circledR}$ (Office 2000, Microsoft Corp., USA). SPSS ${ }^{\circledR}$ for Windows, version 10.0 (SPSS Science, Chicago, Ill., USA), was used for statistical evaluation.

The PSRs were classified as follows: high threshold PSRs, if they discharged during inspiration and rarely during expiration, and low threshold PSRs, if they continued to discharge during expiration [26]. The 15 breaths recorded in each ventilatory period were visualized, and as no obvious differences were found among them, the first three breathing cycles were evaluated. The total number of PSR impulses per ventilatory cycle ( $\left.P S R n_{\text {imp }}\right)$ was obtained by adding up all impulses during in- and expiration. The instantaneous impulse frequency of PSR activity ( $P S R f_{\text {imp }}$ ) was calculated from the time interval of two consecutive spikes (impulses $\cdot \mathrm{s}^{-1}$ ). $P S R f_{\text {imp }}$ at the start of inspiration was determined from the interval between the first two spikes at the beginning of inspiration as defined as the start of increase in flow. Peak PSR $f_{\text {imp }}$ was determined from the shortest interpeak interval during inspiration. Time to peak burst frequency was defined as the time interval between the onset of each breath and the peak $f_{\text {imp. }}$.

Gas flow, $\mathrm{P}_{\mathrm{aw}}$ and $\mathrm{P}_{\mathrm{es}}$ were measured at the different PIPs. The airflow signal was integrated to obtain tidal volume $\left(\mathrm{V}_{t}\right)$ at PIPs. Transpulmonary pressure $\left(\mathrm{P}_{\mathrm{tp}}\right)$ was calculated as $\mathrm{P}_{\mathrm{aw}}-\mathrm{P}_{\mathrm{es}}$. The dynamic lung compliance $\left(C_{L}\right)$ is given as the ratio of $V_{t}$ over $P_{t p}$.

In 9 of the 10 cats all PSRs were classified as high threshold receptors, and in 1 cat the PSR was classified as a low threshold receptor. The values obtained from the single low threshold receptor during inspiration were similar to those from the high threshold receptors and the results from the two types of receptors are presented together. In 7 cats the entire protocol was completed, but in the other 3 cats no measurements at a PIP of $1.2 \mathrm{kPa}$ were obtained. After switching from one PIP to a higher or lower one, stabilization of PSR activity was seen within the first three breaths. Instillation of PFC was well tolerated in all animals, and no coughing or gasping occurred.

Data are presented as mean \pm SD. Paired two-tailed t-tests were applied for comparison of data between GV and PLV. The level of significance was set at $\mathrm{p}<0.05$ for all tests. Pearson's correlation coefficient was used to describe the linear correlation (r) between $P S R f_{\text {imp }}$ and $\mathrm{P}_{\mathrm{tp}}$.

\section{Results}

\section{PSR Activity}

All PSRs recorded in the 10 cats maintained a similar phasic character with increased impulse frequency during inspiration both during PLV and GV, with some differences in impulse distribution (fig. 1).

Peak $P S R f_{\text {imp }}$, and $P S R f_{\text {imp }}$ at the start of inspiration, during GV and PLV are illustrated in figure $2 \mathrm{~A}$ and $\mathrm{B}$. $P S R f_{\text {imp }}$ at start of inspiration was lower at PIP $1.2 \mathrm{kPa}$ and higher at PIP $2.7 \mathrm{kPa}$ during PLV than during GV $\left(\mathrm{p}<0.05\right.$; fig. 2B). Peak $P S R f_{\text {imp }}$ was lower at PIP $1.2 \mathrm{kPa}$ $(\mathrm{p}<0.05)$ and somewhat lower at PIP $2.7 \mathrm{kPa}(\mathrm{p}=0.10)$ during PLV than during GV (fig. 2 A), also causing a smaller number of PSR impulses at these two settings during PLV than during GV ( $\mathrm{p}<0.05$; fig. $2 \mathrm{C})$. Time to peak $P S R f_{\text {imp }}$ was between 0.39 and $0.47 \mathrm{~s}$ during both $\mathrm{GV}$ and PLV and did not differ between the two conditions. There was almost the same linear correlation between $P S R f_{\text {imp }}$ and $P_{t p}$ during GV and PLV as demonstrated in a representative example (fig. 3). Pearson's correlation coefficient between $P S R f_{\text {imp }}$ and $\mathrm{P}_{\text {tp }}$ ranged from 0.6 to 0.8 (mean values) during both GV and PLV.

\section{Lung Mechanics}

Only when a low PIP of $1.2 \mathrm{kPa}$ was applied was $\mathrm{V}_{\mathrm{t}}$ significantly higher during GV than during PLV ( $\mathrm{p}<$ 0.01) (table 1, fig. 4). At higher pressures, $V_{t}$ did not differ between the two forms of ventilation. Dynamic $C_{L}$ was lower during PLV than during GV both at a PIP of $1.2 \mathrm{kPa}(\mathrm{p}<0.01)$ and $1.8 \mathrm{kPa}(\mathrm{p}<0.05)$ (table 1$)$.

When peak $P S R f_{\text {imp }}$ values obtained from measurements during GV and PLV were related to their $V_{\mathrm{t}}$ values, a curvilinear relationship was observed at PIPs of 1.2$2.2 \mathrm{kPa}$. At a very high $\mathrm{V}_{\mathrm{t}}$ of $44-45 \mathrm{ml} / \mathrm{kg}$ causing hyperventilation (table 1), GV tended to give a higher peak $P S R$ $f_{\text {imp (fig. 4). }}$.

\section{Arterial Blood Gases}

Blood gases were in the normal range at a PIP of $1.2 \mathrm{kPa}$ (table 1). When PIPs of 1.8, 2.2 and $2.7 \mathrm{kPa}$ were applied, all cats were hyperventilated during GV and PLV 


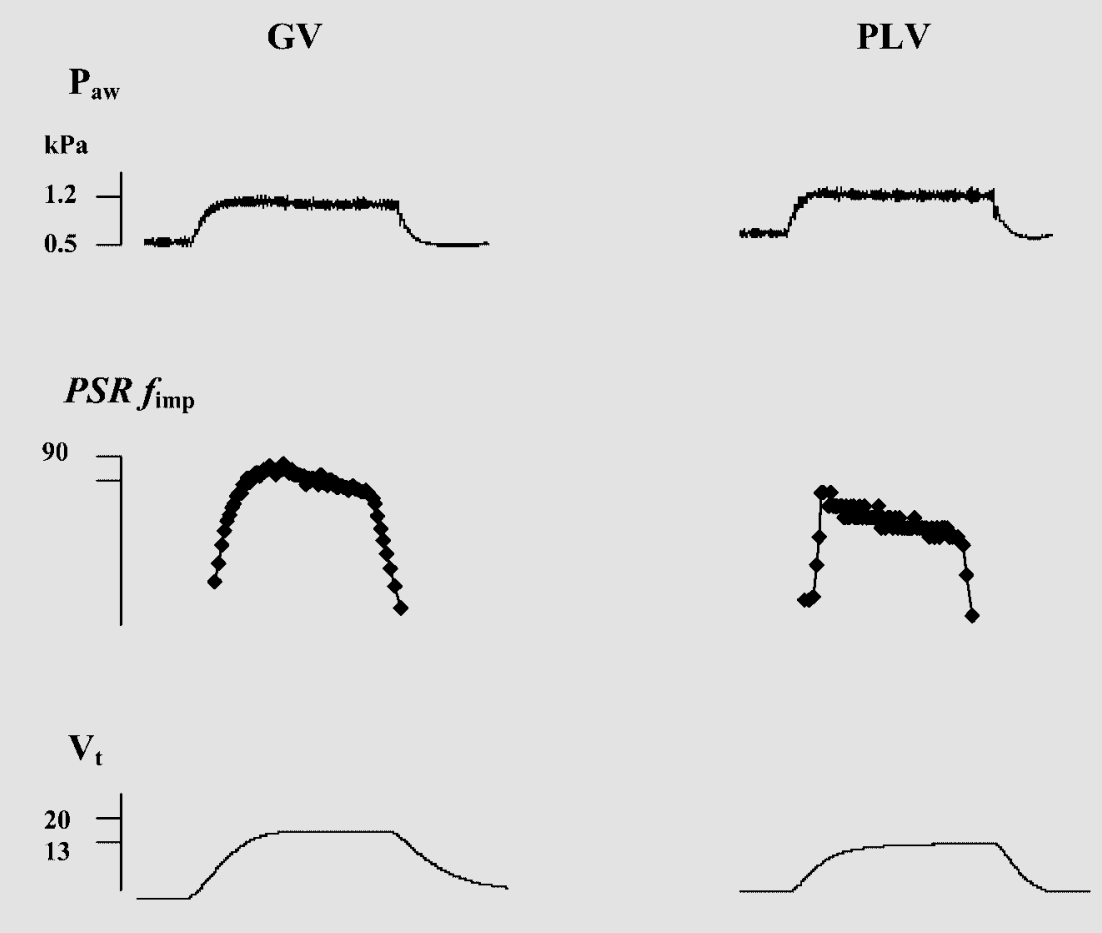

Fig. 1. Airway pressure $\left(\mathrm{P}_{\mathrm{aw}}\right)$, instantaneous impulse frequency of slowly adapting pulmonary stretch receptor $\left(P S R f_{\text {imp }}\right)$, tidal volume $\left(\mathrm{V}_{\mathrm{t}}\right)$ and raw PSR activity during gas ventilation $(\mathrm{GV})$ and partial liquid ventilation (PLV) with a positive inspiratory pressure (PIP) of $1.2 \mathrm{kPa}$ in 1 cat.

\section{Raw PSR}
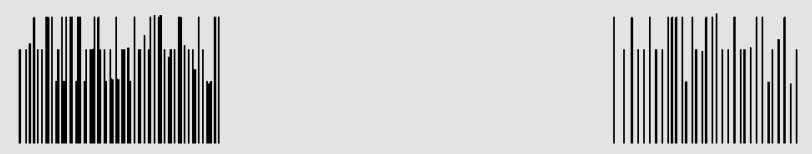

(table 1). Blood gases differed between GV and PLV at a PIP of $1.2 \mathrm{kPa}$. Oxygenation was always sufficient, with a $\mathrm{PaO}_{2}>14 \mathrm{kPa}$.

\section{Discussion}

The most important finding in this study was that PSRs maintained their phasic character with increased impulse frequency during inspiration during PLV. Differences in PSR $f_{\text {imp }}$ between the two conditions were observed at a PIP of $1.2 \mathrm{kPa}$ at normoventilation and at a PIP of $2.7 \mathrm{kPa}$ at severe hyperventilation. Since the $\mathrm{PaCO}_{2}$ values were almost equal during GV and PLV at all studied PIPs except at $1.2 \mathrm{kPa}, \mathrm{PaCO}_{2}$ cannot be con- sidered to be a confounder. PSR activity was found not to be higher during PLV than during GV in cats with healthy lungs.

The PFC we used evaporates very slowly because of its low vapour pressure, but its high viscosity might influence the distribution of PFC in the lung and increase the work of breathing [27]. Theoretically the high density of PFC and the altered surface tension of a liquid-filled lung might result in overdistension of the alveoli leading to a higher discharge by the mechanoreceptors in the distal airways. Our findings do not support this alternative, as the PSR discharge during PLV was either equal to the discharge during GV or even lower.

In the present study all receptors maintained an impulse pattern with phasic character during PLV similar to 
Fig. 2. A Peak instantaneous impulse frequency of slowly adapting pulmonary stretch receptor $\left(P S R f_{\text {imp }}\right)$ with use of different positive inspiratory pressures (PIPs) during gas ventilation $(\mathrm{GV})$ and partial liquid ventilation (PLV) in 10 cats. Data are mean $\pm \mathrm{SD}$; $* \mathrm{p}<0.05$ between GV and PLV. B Instantaneous impulse frequency of slowly adapting $P S R f_{\text {imp }}$ at the start of inspiration with use of different PIPs during GV and PLV in 10 cats. Data are mean $\pm \mathrm{SD} ; * \mathrm{p}<0.05$ between GV and PLV. C The total number of slowly adapting pulmonary stretch receptor impulses per ventilatory cycle $\left(P S R n_{\text {imp }}\right)$ during GV and PLV in relation to PIP in 10 cats. Data are mean $\pm \mathrm{SD} ; * \mathrm{p}<0.05$ between GV and PLV.
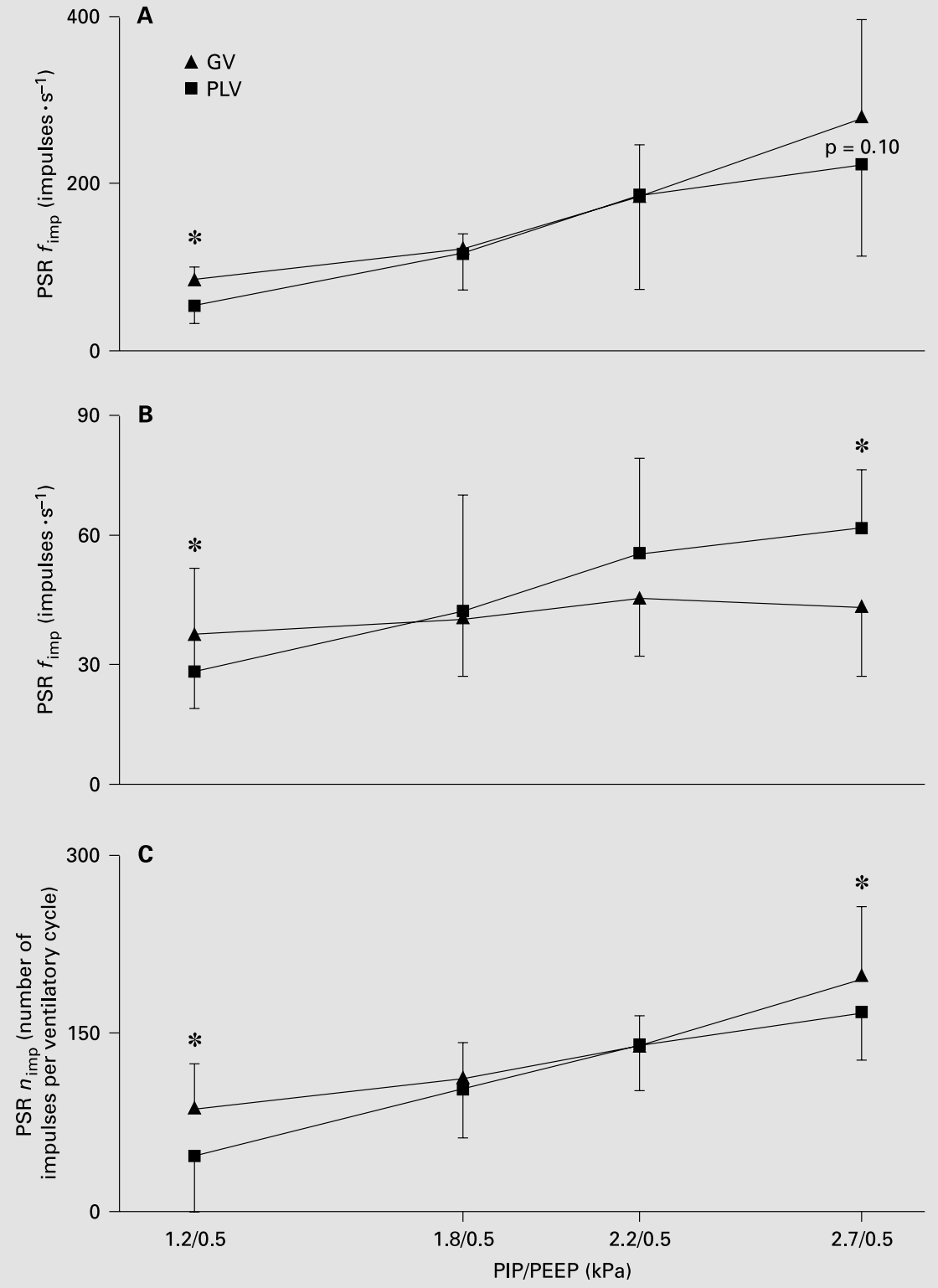

that during GV. It was considered that filling the lung with PFC might possibly increase the functional residual capacity and influence the PSR discharge pattern during expiration, especially that from low threshold receptors located in the distal airways. In this study, however, all high threshold receptors maintained their low burst activity during expiration and the single low threshold receptor discharged continuously during expiration with both PLV and GV.

Pulmonary Stretch Receptor Activity

during Partial Liquid Ventilation
The smaller number of PSR impulses, the lower PSR activity at the start of inspiration and the lower peak PSR activity at a PIP of $1.2 \mathrm{kPa}$ during PLV compared to those during GV might be related to the fact that at a low PIP a viscous and heavy PFC will not easily be displaced into the distal segments of the lung. At a PIP of $2.7 \mathrm{kPa}$ the higher PSR activity at the start of inspiration and the lower peak PSR activity during PLV than during GV may indicate that PFC remained inside the distal airways during the rapid changes in volume and pressure occurring in

Biol Neonate 2004;86:73-80 
Fig. 3. Correlation ( $r$ ) between instantaneous impulse frequency of slowly adapting pulmonary stretch receptor (PSR $f_{\text {imp }}$ ) and transpulmonary pressure $\left(\mathrm{P}_{\mathrm{tp}}\right)$ at positive inspiratory pressure (PIP) $2.7 \mathrm{kPa}$ during gas ventilation $(\mathrm{GV})(\mathbf{A})$ and partial liquid ventilation (PLV) (B) in 1 cat.
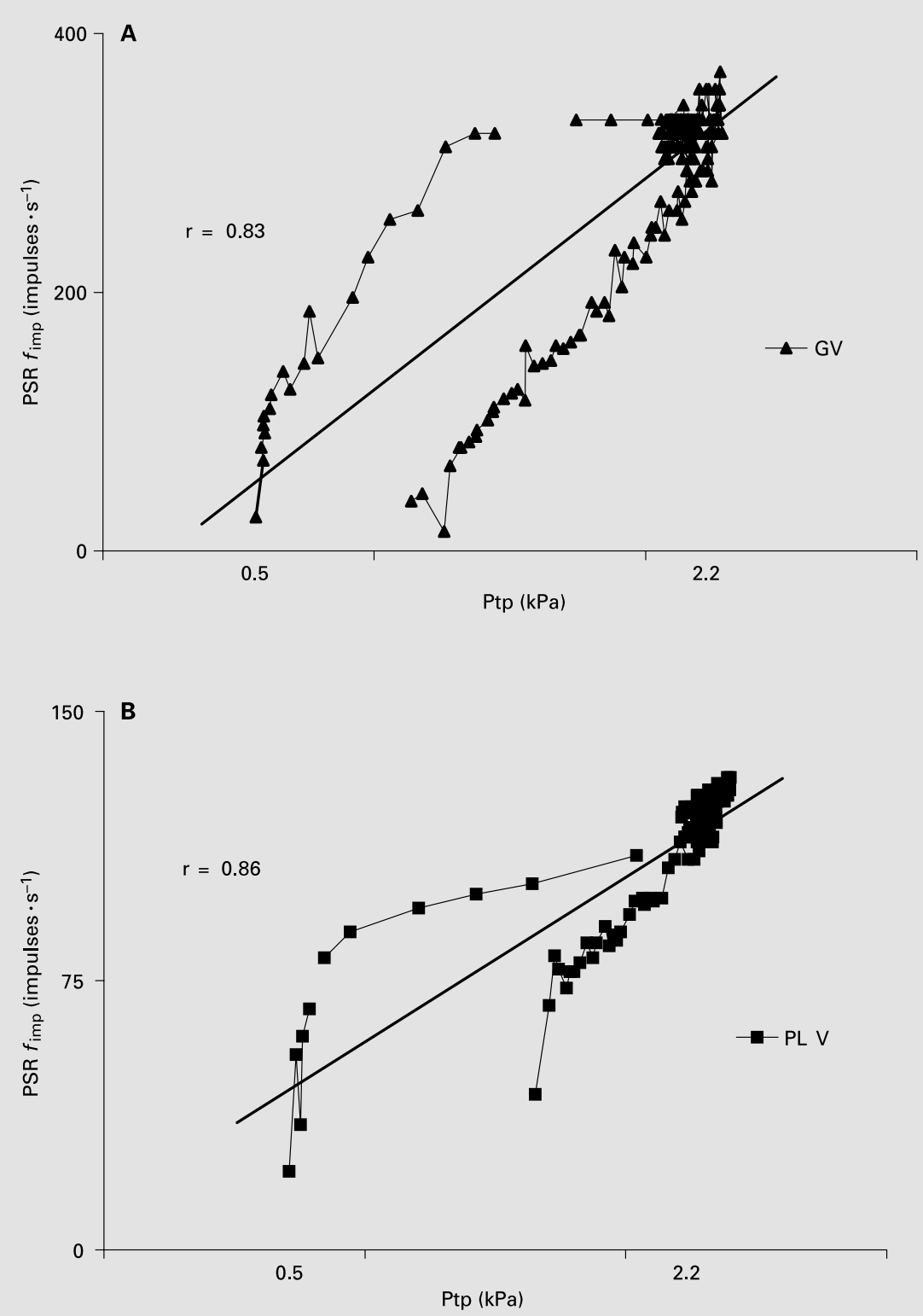

the breathing cycle. Besides being influenced by volume and pressure $[28,29]$, the activity of the receptors may be affected by the flow rate [17], which might be lower during PLV and cause smaller tidal movements than with GV. At the highest PIP used, the higher PSR activity at the start of inspiration during PLV might indicate more marked stretching of the lung tissue at the beginning of inspiration, probably as a consequence of the inertia of PFC, whereas the lower peak PSR activity during PLV compared to that during GV might indicate less stretching at the highest ventilatory pressure. This could imply less mechanical stretching at very high pressures during PLV compared to GV. Thus, PLV might reduce lung damage when very high airway pressures are applied.

Lower lung compliance during PLV than during GV in animals with healthy lungs has been reported elsewhere $[30,31]$, and this is considered to be independent of the ventilatory mode applied. It could be explained by the higher viscosity and density of the PFC compared to gas [31]. In none of the ventilatory settings at PIPs higher 
Table 1. Lung mechanics and blood gases during GV and PLV with different PIPs in 10 cats (values are means \pm SD)

\begin{tabular}{|c|c|c|c|c|c|c|c|c|}
\hline & \multicolumn{2}{|c|}{ PIP $1.2 \mathrm{kPa}$} & \multicolumn{2}{|c|}{ PIP $1.8 \mathrm{kPa}$} & \multicolumn{2}{|c|}{ PIP $2.2 \mathrm{kPa}$} & \multicolumn{2}{|c|}{ PIP $2.7 \mathrm{kPa}$} \\
\hline & GV & PLV & GV & PLV & GV & PLV & GV & PLV \\
\hline $\mathrm{Vt}, \mathrm{ml} / \mathrm{kg}$ & $20 \pm 7$ & $11 \pm 4^{*}$ & $31 \pm 4$ & $29 \pm 7$ & $38 \pm 4$ & $38 \pm 8$ & $44 \pm 5$ & $45 \pm 9$ \\
\hline $\mathrm{C}_{\mathrm{L}}, \mathrm{ml} / \mathrm{kPa}$ & $48 \pm 10$ & $21 \pm 6^{*}$ & $54 \pm 19$ & $43 \pm 16^{*}$ & $50 \pm 10$ & $49 \pm 19$ & $46 \pm 10$ & $46 \pm 15$ \\
\hline Arterial $\mathrm{pH}$ & $7.5 \pm 0.1$ & $7.3 \pm 0.0^{*}$ & $7.6 \pm 0.1$ & $7.5 \pm 0.1$ & $7.7 \pm 0.1$ & $7.6 \pm 0.1$ & $7.7 \pm 0.1$ & $7.7 \pm 0.1$ \\
\hline $\mathrm{PaCO}_{2}, \mathrm{kPa}$ & $4.2 \pm 0.5$ & $6.0 \pm 0.7 *$ & $3.1 \pm 0.6$ & $3.6 \pm 1.2$ & $2.2 \pm 0.2$ & $2.4 \pm 0.4$ & $2.0 \pm 0.7$ & $2.3 \pm 0.6$ \\
\hline
\end{tabular}

$\mathrm{GV}=$ Gas ventilation; $\mathrm{PLV}=$ partial liquid ventilation; $\mathrm{PIP}=$ peak inspiratory pressure; $\mathrm{V}_{\mathrm{t}}=$ tidal volume; $\mathrm{C}_{\mathrm{L}}=\mathrm{dynamic}_{\mathrm{fung}}$ compliance.

* Significant difference $(\mathrm{p}<0.05)$ between GV and PLV.

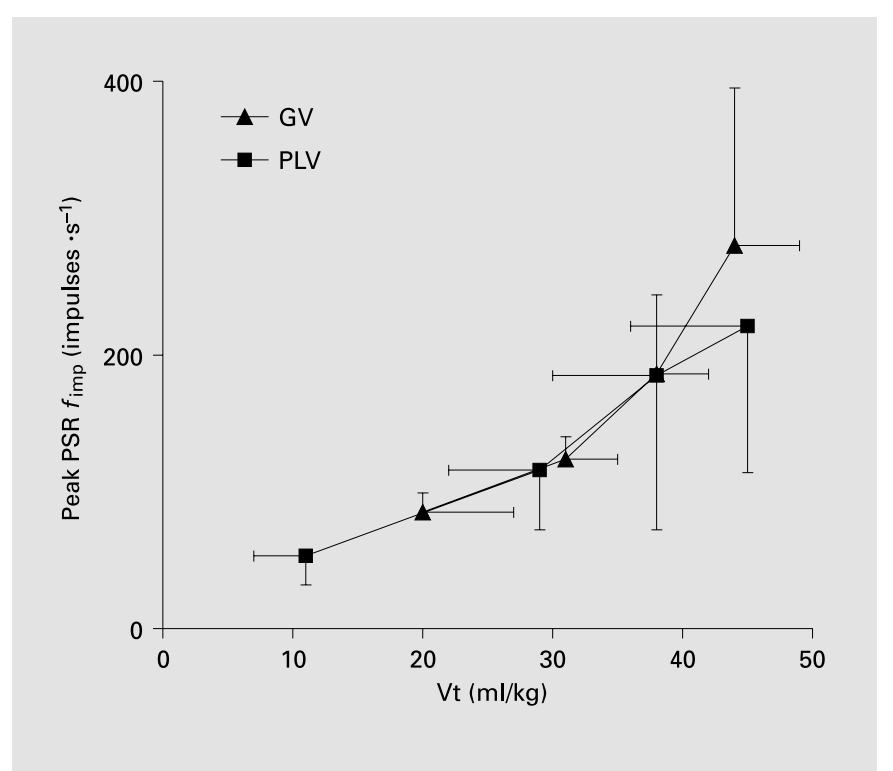

Fig. 4. Peak instantaneous impulse frequency of slowly adapting pulmonary stretch receptor ( $\left.P S R f_{\text {imp }}\right)$ in relation to tidal volume $\left(\mathrm{V}_{\mathrm{t}}\right)$ during gas ventilation (GV) and partial liquid ventilation (PLV) in 10 cats.

than $1.2 \mathrm{kPa}$ were there any significant differences in tidal volumes that could have influenced the results of PSR activity. A linear correlation between $P S R f_{\text {imp }}$ and $\mathrm{P}_{\mathrm{tp}}$ similar to that reported by Davis et al. [28] during GV was observed during PLV in our study.

Normoventilation was achieved with the lowest PIP of $1.2 \mathrm{kPa}$, but all settings with higher ventilation pressures caused hyperventilation of the cats (table 1), and the $\mathrm{PaCO}_{2}$ values during GV and PLV were almost equal at all applied peak pressures higher than $1.2 \mathrm{kPa}$. The changes in impulse activity were immediate and did not alter with time. Sant'Ambrogio et al. [32] found that the inhibitory effects of $\mathrm{CO}_{2}$ on PSR discharge that occurred when the end-tidal $\mathrm{pCO}_{2}$ was increased did not depend on the bronchomotor tone, but seemed to be mediated by local variations in $\mathrm{H}^{+}$concentrations in the distal airways. According to Luijendijk [33], the distance of the PSRs from the airway lumen might also play a role in the timing of their reaction to a change in $\mathrm{pCO}_{2}$ in the airways. Coleridge et al. [34] found an augmented discharge of PSRs at extremely low $\mathrm{CO}_{2}$ concentrations in the vascularly isolated lung. Bradley et al. [35] also found increased PSR activity at extremely low end-tidal $\mathrm{pCO}_{2}$, but in their study a change in arterial $\mathrm{pCO}_{2}$ was not accompanied by a change in PSR discharge. Although we cannot entirely exclude the possibility of additional influence of end-tidal $\mathrm{pCO}_{2}$ on PSR discharge in the present study, the close similarity of the arterial $\mathrm{pCO}_{2}$ levels at the PIP settings of $1.8,2.2$ and $2.7 \mathrm{kPa}$, both during GV and PLV, more likely implied equal influence on the PSR discharge at these settings.

In the present study the activity of one slowly adapting PSR was studied in each animal without knowledge of the location of the receptor in the lung and without any information on the activity of other receptors that may have contributed to the afferent information to the respiratory centre. Even if it is possible that the distribution of gas or liquid in the lung might influence the PSR activity, the recorded PSR activity in any one animal did not differ greatly from that in the other animals studied.

This study shows that PSRs maintain a phasic character both during PLV and GV. There are significantly higher PSR $f_{\text {imp }}$ during GV than during PLV at the start of insufflation and also in the number of PSR impulses dur- 
ing the insufflation at normoventilation. At the highest PIP peak $P S R f_{\text {imp }}$ was higher during GV than during PLV. We therefore have to reject the hypothesis that peak PSR activity is higher during PLV than during GV in cats with healthy lungs. There is no indication of excessive stretching of the lung with PLV, which is important to know if PLV is to be applied in newborn infants.

\section{Acknowledgements}

The authors are indebted to Barbro Kjällström for skilled laboratory assistance. This study was supported financially by the Swedish Research Council (K2003-73VX-14729-01A, K2002-72X-0499826B), HRH the Crown Princess Lovisa's Fund for Scientific Research, the Åke Wiberg Foundation and the Medical Faculty of Uppsala University.

\section{References}

1 Fuhrman BP, Paczan PR, DeFrancisis M: Perfluorocarbon-associated gas exchange. Crit Care Med 1991;19:712-722.

2 Leach CL, Fuhrman BP, Morin FC III, Rath MG: Perfluorocarbon-associated gas exchange (partial liquid ventilation) in respiratory distress syndrome: A prospective, randomized, controlled study. Crit Care Med 1993;21: 1270-1278.

3 Shaffer TH, Lowe CA, Bhutani VK, Douglas PR: Liquid ventilation: effects on pulmonary function in distressed meconium-stained lambs. Pediatr Res 1984;18:47-52.

4 Hirschl RB, Croce M, Gore D, Wiedemann H, Davis K, Zwischenberger J, Bartlett RH: Prospective, randomized, controlled pilot study of partial liquid ventilation in adult acute respiratory distress syndrome. Am J Respir Crit Care Med 2002; 165:781-787.

5 Greenspan JS, Wolfson MR, Shaffer TH: Liquid ventilation: Clinical experiences. Biomed Instrum Technol 1999;33:253-259.

6 Shaffer TH, Foust R III, Wolfson MR, Miller TF Jr: Analysis of perfluorochemical elimination from the respiratory system. J Appl Physiol 1997;83:1033-1040.

7 Wolfson MR, Greenspan JS, Shaffer TH: Liquid-assisted ventilation: An alternative respiratory modality. Pediatr Pulmonol 1998;26:4263.

8 Miller TF, Milestone B, Stern R, Shaffer TH, Wolfson MR: Effects of perfluorochemical distribution and elimination dynamics on cardiopulmonary function. J Appl Physiol 2001;90: 839-849.

9 Tutuncu AS, Houmes RJ, Bos JA, Wollmer P, Lachmann B: Evaluation of lung function after intratracheal perfluorocarbon administration in healthy animals. Crit Care Med 1996;24: 274-279.

10 Bendel-Stenzel EM, Mrozek JD, Bing DR, Meyers PA, Connett JE, Mammel MC: Dynamics of spontaneous breathing during patient-triggered partial liquid ventilation. Pediatr Pulmonol 1998;26:319-325.

11 Mates EA, Hildebrandt J, Jackson JC, TarczyHornoch P, Hlastala MP: Shunt and ventilation-perfusion distribution during partial liquid ventilation in healthy piglets. J Appl Physiol 1997;82:933-942.
12 Canning BJ, Widdicombe JG: Innervation of the airways: introduction. Respir Physiol 2001; 125:1-2.

13 Widdicombe JG: Airway receptors. Respir Physiol 2001;125:3-15.

14 Bartlett D Jr, Jeffery P, Sant'Ambrogio G, Wise JC: Location of stretch receptors in the trachea and bronchi of the dog. J Physiol 1976; 258:409-420.

15 Sant'Ambrogio G: Information arising from the tracheobronchial tree of mammals. Physiol Rev 1982;62:531-565.

16 Schelegle ES, Green JF: An overview of the anatomy and physiology of slowly adapting pulmonary stretch receptors. Respir Physiol 2001;125:17-31.

17 Pack AI, Ogilvie MD, Davies RO, Galante RJ: Responses of pulmonary stretch receptors during ramp inflations of the lung. J Appl Physiol 1986;61:344-352.

18 Widdicombe JG: The site of pulmonary stretch receptors in the cat. J Physiol 1954;125:336351.

19 Kirkpatrick SM, Olinsky A, Bryan MH, Bryan AC: Effect of premature delivery on the maturation of the Hering-Breuer inspiratory inhibitory reflex in human infants. J Pediatr 1976;88: 1010-1014.

20 Stocks J, Dezateux C, Hoo AF, Rabbette PS, Costeloe K, Wade A: Delayed maturation of Hering-Breuer inflation reflex activity in preterm infants. Am J Respir Crit Care Med 1996; 154:1411-1417.

21 Lalani S, Remmers JE, Green FH, Bukhari A, Ford GT, Hasan SU: Effects of vagal denervation on cardiorespiratory and behavioral responses in the newborn lamb. J Appl Physiol 2001;91:2301-2313.

22 Bartlett D Jr, Sant'Ambrogio G, Wise JC: Transduction properties of tracheal stretch receptors. J Physiol 1976;258:421-432.

23 Yu J, Pisarri TE, Coleridge JC, Coleridge HM: Response of slowly adapting pulmonary stretch receptors to reduced lung compliance. J Appl Physiol 1991;71:425-431.

24 Madler HJ, Gehrhardt B, Schaller P, Bohme B, Schulze A, Gmyrek D: Equipment for microcomputer-controlled measurement in the evaluation of respiratory mechanical parameters in premature and newborn infants. Kinderärztl Prax 1985;53:113-117.
25 Ehrhardt H, Sindelar R, Jonzon A, RiegerFackeldey E, Schaller P, Schulze A, Sedin G: Effects of the inspiratory pressure waveform during patient-triggered ventilation on pulmonary stretch receptor and phrenic nerve activity in cats. Crit Care Med 2001;29:1207-1214.

26 Paintal AS: Re-evaluation of respiratory reflexes. Q J Exp Physiol Cogn Med Sci 1966;51: 151-163.

27 Jeng MJ, Yang SS, Wolfson MR, Shaffer TH: Perfluorochemical combinations for acute lung injury: An in vitro and in vivo study in juvenile rabbits. Pediatr Res 2003;53:81-88.

28 Davis H, Fowler W, Lambert E: Effect of volume and rate of inflation and deflation on transpulmonary pressure and response of pulmonary stretch receptors. Am J Physiol 1956; 187:558-566.

29 Sant'Ambrogio FB, Sant'Ambrogio G, Fisher JT: Lung mechanics and activity of slowly adapting airway stretch receptors. Eur Respir J 1988;1:685-690.

30 Shaffer TH, Douglas PR, Lowe CA, Bhutani VK: The effects of liquid ventilation on cardiopulmonary function in preterm lambs. Pediatr Res 1983;17:303-306.

31 Hummler HD, Schulze A, Pohlandt F, Thome U: Dynamics of breathing during partial liquid ventilation in spontaneously breathing rabbits supported by elastic and resistive unloading. Pediatr Res 2000;47:392-397.

32 Sant'Ambrogio G, Miserocchi G, Mortola J: Transient responses of pulmonary stretch receptors in the dog to inhalation of carbon dioxide. Respir Physiol 1974;22:191-197.

33 Luijendijk SC: Within-breath $\mathrm{PCO}_{2}$ levels in the airways and at the pulmonary stretch receptor sites. J Appl Physiol 1983;55:1333-1340.

34 Coleridge HM, Coleridge JC, Banzett RB: II. Effect of $\mathrm{CO}_{2}$ on afferent vagal endings in the canine lung. Respir Physiol 1978;34:135-151.

35 Bradley GW, Noble MI, Trenchard D: The direct effect on pulmonary stretch receptor discharge produced by changing lung carbon dioxide concentration in dogs on cardiopulmonary bypass and its action on breathing. J Physiol 1976;261:359-373. 